\title{
Analisis Kepercayaan Pasien Rawat Inap pada RSUD di Propinsi Kepulauan Riau
}

\author{
HADIYATI \\ Fakultas Ekonomi Universitas Lancang Kuning Pekanbaru \\ Jalan Yos Sudarso KM 8 Rumbai \\ Telp. (0761) 52581. Email: hadiyatisuroto@yahoo.co.id
}

\begin{abstract}
Speaking of health problems, this is a form of investment for the community, because health is a basic capital that is needed by all people to be able to move in accordance with the duties and responsibilities of each. Hospital patient requires trust, trust is a behavior in which leads to an assessment of a given action or attitude. This belief affect the sustainability of a service that sediri. In the case of hospital services, the service becomes essential in making the patient wants and continue to use the services of the hospital. Many of the complaints and prove that the hospitals Kepulauan Riau, the most fundamental problems that need to be built is a matter of the ability of doctors daam cure the patient.
\end{abstract}

Keywords: Confidence, ability, integrity and Policy

Berbicara masalah kesehatan, ini merupakan bentuk investasi bagi masyarakat, sebab kesehatan merupakan modal dasar yang sangat diperlukan oleh segenap masyarakat untuk dapat beraktivitas sesuai dengan tugas dan tanggung jawabnya masing-masing, sehingga mampu menghasilkan sesuatu yang bermanfaat bagi diri sendiri dan keluarga. Bila kondisi kesehatan bermasalah bukan tidak mungkin seluruh harta dan kekayaan akan habis digunakan untuk memperoleh kesehatan tersebut. Dalam Undang-Undang Republik Indonesia Nomor 23 Tahun 1992 tentang Pokok-Pokok Kesehatan disebutkan bahwa kesehatan rakyat adalah salah satu modal pokok dalam rangka pertumbuhan dan kehidupan bangsa dan mempunyai peranan penting dalam penyelesaian kesehatan nasional dan penyusunan masyarakat sosialis Indonesia. Pemerintah harus mengusahakan bidang kesehatan dengan sebaik-baiknya, yaitu menyediakan pelayanan kesehatan yang memadai dan dapat diakses dengan mudah oleh masyarakat.

Pemeliharaan dan perlindungan kesehatan sangatlah penting untuk mencapai derajat kesehatan dan kesejahteraan yang tinggi, namun kenyataan rendahnya derajat kesehatan masyarakat disebabkan oleh ketidak mampuan mereka untuk mendapatkan pelayanan kesehatan, karena mahalnya biaya kesehatan yang harus dibayar oleh masyarakat. Tingginya tingkat kemiskinan di Indonesia, menyebabkan masyarakat tidak mampu memenuhi kebutuhan pelayanan kesehatan yang tergolong masih mahal. Banyak penelitian yang menyatakan bahwa kesehatan berbanding terbalik dengan kemiskinan, makin tinggi tingkat kemiskinan masyarakat, maka derajat kesehatan masyarakat akan semakin rendah.

Rumah sakit sebagai salah satu institusi pelayanan kesehatan, memegang peranan yang sangat penting dalam pembangunan kesehatan. Rumah sakit mempunyai misi memberikan pelayanan kesehatan yang bermutu dan terjangkau oleh masyarakat dalam rangka meningkatkan derajat kesehatan masyarakat, dan misi khusus adalah aspirasi yang ditetapkan dan ingin dicapai oleh pemilik rumah sakit. Rumah sakit adalah rumah sakit yang memberikan pelayanan kesehatan semua jenis penyakit dari yang bersifat dasar sampai spesifik. Menurut Keputusan Menteri Kesehatan RI No. 983 Tahun 1992, tugas pokok rumah sakit adalah melaksanakan upaya kesehatan secara berdaya guna dan berhasil dengan mengutamakan upaya penyembuhan (kuratif) dan pemulihan (rehabilitatif) yang dilaksanakan secara serasi dan terpadu dengan upaya peningkatan 
(promotif) dan pencegahan (preventif) serta melaksanakan upaya rujukan. Dalam rangka menyusun tatanan pelayanan rumah sakit, peningkatan serta pengembangan pelayanan kesehatan dan fungsi rumah sakit. Departemen Kesehatan RI menentukan standar pelayanan rumah sakit yang berisi kriteria-kriteria penting mengenai jenis disiplin pelayanan yang berkaitan terutama dengan struktur dan proses pelayanan. Selain itu, peningkatan pelayanan kesehatan bukanlah semata-mata ditentukan oleh tersedianya fasilitas fisik yang baik saja. Namun yang lebih penting adalah sikap mental dan kualitas profesionalisme para personel yang melayaninya.

Berdasarkan Undang-Undang Republik Indonesia Nomor 44 Tahun 2009 Tentang Rumah Sakit mempunyai tugas memberikan pelayanan kesehatan perorangan secara paripurna, pasal 5 untuk menjalankan tugas sebagaimana dimaksud dalam Pasal 4, Rumah Sakit mempunyai fungsi (a) penyelenggaraan pelayanan pengobatan dan pemulihan kesehatan sesuai dengan standar pelayanan rumah sakit; (b) pemeliharaan dan peningkatan kesehatan perorangan melalui pelayanan kesehatan yang paripurna tingkat kedua dan ketiga sesuai kebutuhan medis; (c) penyelenggaraan pendidikan dan pelatihan sumber daya manusia dalam rangka peningkatan kemampuan dalam pemberian pelayanan kesehatan; (d) penyelenggaraan penelitian dan pengembangan serta penapisan teknologi bidang kesehatan dalam rangka peningkatan pelayanan kesehatan dengan memperhatikan etika ilmu pengetahuan bidang kesehatan.

Selanjutnya Peraturan Menteri Kesehatan Republik Indonesia NOMOR 340/MENKES/PER/III/2010 tentang klasifikasi rumah sakit, Bab II, pasal 3 bahwa rumahsakit harus mempunyai kemampuan pelayanan sekurang-kurangnya pelayanan medik, gawat darurat, pelayanan keperawatan, rawat jalan, rawat inap, opersi/bedah, pelayanan medik spesialis dasar, penunjang medik, farmasi, gizi, sterilisasi, rekam medik, pelayanan administrasi dan manajemen, penyuluhan kesehatan masyarakat, pemulasaraan jenazah, laundry, dan ambulance, pemeliharaan sarana rumah sakit, serta pengolahan limbah. dan Bab III, pasal 4 tentang klasifikasi Rumah Sakit : berdasarkan fasilitas dan kemampuan pelayanan, Rumah Sakit diklasifikasikan menjadi : Rumah Sakit Kelas A, B, C dan D, dan pasal 5 Klasifikasi Rumah Sakit ditetapkan berdasarkan : Pelayanan, Sumber Daya Manusia, Peralatan, Sarana Prasarana, dan Administrasi dan Manajemen.

Kondisi pelayanan rumah sakit di Indonesia sesuai temuan Hardiman (2003), bahwa sistem pelayanan kesehatan di Indonesia belum baik. Rumah sakit belum mampu menjamin mutu pelayanan kesehatan, hal tersebut seperti : dokter sering terlambat datang, sehingga pasien harus menunggu lama untuk mendapat pelayanan, belum menyediakan ruang tunggu yang nyaman, belum ada kontinuitas pelayanan, belum bisa menjamin waktu penyerahan obat serta belum mampu membuat sistem peresepan on line lewat komputer. Rumah sakit di Indonesia belum banyak yang berorienasi pada konsumen/pasien (consumer oriented), belum memberikan kemudahan akses pelayanan bagi pasien untuk berobat ke rumah sakit.

Berbicara masalah pelayanan jasa kesehatan sangat tidak terlepas dengan masalah perilaku. Perilaku (behavior) mengacu kepada tindakan nyata pelanggan yang dapat diobservasi secara langsung, misalnya perilaku pelanggan di toko atau di pusat perbelanjaan. Afeksi dan kognisi mengacu kepada perasaan dan pikiran, sedangkan perilaku berhubungan dengan apa yang sebenarnya dilakukan oleh pelanggan. Berbagai jenis perilaku dapat ditingkatkan melalui penggunaan pendekatan perilaku, misalnya berbagai insentif yang diberikan produsen atau pemasar perusahaan dapat meningkatkan pembelian pelanggan terhadap sesuatu produk. Begitu juga, berbagai jenis perilaku pelanggan yang tidak diinginkan dapat dikurangi melalui penerapan analisis perilaku, misalnya berbagai jenis intervensi 
dapat menurunkan konsumsi rokok dan minuman keras. Proses perilaku pelanggan menurut Wells dan Prensky (1996:46) dapat dipengaruhi oleh lingkungannya.

Perilaku ini memberikan kepercayaan, sebuah rumah sakit perlu membangun kepercayaan yang tinggi bagi pasien setelah berobat, kepercayaan dibangun melalui kemampuan dalam memberikan pelayanan kepada pasien, memiliki komitmen untuk menjalankan bisnis dengan benar sesuai dengan yang dijanjikan dan komitmen untuk memberikan kepuasan secara terus menerus sejalan dengan pendapat Gurviez and Korchia $(2003,362)$ dalam penelitiannya menyebutkan terdapat tiga elemen yang membentuk kepercayaan, yaitu : (1) Kemampuan (Ability), Kemampuan berkaitan dengan kompetensi dan karakteristik dari para pelaku (penjual, karyawan, dll) dalam memberikan layanan kepada konsumennya; (2) Integritas (Integrity), merupakan komitmen perilaku dari para penyedia jasa untuk menjalankan aktivitas bisnis yang benar-benar sesuai dengan janji yang telah disampaikannya kepada konsumen; (3) Kebajikan (Benevolence), merupakan komitmen penyedia jasa untuk mampu memberikan kepuasan kepada konsumen.

Kepercayaan pasien terhadap rumah sakit sangat penting karena, kepercayaan merupakan modal utama dalam mewujudkan visi, misi dan tujuan rumah sakit. Pasien yang percaya dan yakin kepada satu rumah sakit, dia akan mempercayakan seluruh keperluan pengobatan ataupun pencegahan untuk penyakit yang dia derita. Bila terjadi demikian, hal ini menjadi sebuah keuntungan untuk rumah sakit baik dalam jangka pendek maupun jangka panjang. Pasien yang sudah percaya terhadap rumah sakit tertentu secara tidak langsung pada kesempatan tertentu akan merekomendasikan kepada pihak lain tentang pelayanan yang baik yang ia terima dari rumah sakit, dengan demikian sudah ikut mempromosikan kepada calon-calon pasien lainnya dan ini adalah salah satu bentuk loyalitas pasien. Tetapi jika sebaliknya, sebuah rumah sakit yang kurang memiliki kepercayaan dari masyarakat, maka dalam jangka panjang akan ditinggalkan, dan pada akhirnya rumah sakit itu akan kehilangan pasien dan akhirnya bangkrut karena tidak ada pasien.

Morgan dan Hunt, (1994:23) menyatakan kepercayaan sebagai kemauan untuk mempercayai pihak lain yang telah diyakini. Definisi yang digambarkan oleh Rotters (1997:651) bahwa kepercayaan adalah harapan secara umum seseorang atau dengan kata lain dapat dipercaya. Kedua definisi tersebut juga menekankan pentingnya kepercayaan. Kepercayaan (trust) adalah keadaan psikologis berisi keinginan untuk menerima kekurangan/kelemahan, berdasarkan perilaku yang positif terhadap intensi atau perilaku atau lainnya dalam keadaan berisiko dan saling tergantung, sedangkan Robbin (2003:336) menyatakan kepercayaan (trust) merupakan harapan yang positif bahwa yang lain tidak akan bertindak secara oportunistik.

Kreitner dan Kinicki (2001:422) mengemukakan pula bahwa kepercayaan merupakan keyakinan satu pihak mengenai maksud dan perilaku pihak yang lainnya. Dalam hal ini, kepercayaan konsumen didefinisikan sebagai harapan konsumen bahwa penyedia jasa dapat dipercaya atau diandalkan dalam memenuhi janjinya. Menurut Callaghan dan Shaw(1995) dimensi kepercayaan didefinisikan sebagai dimensi hubungan bisnis yang menentukan tingkat di mana orang merasa dapat bergantung pada integritas janji yang ditawarkan oleh orang lain. Mengacu pada ketentuan di bidang psikologi sosial dan pemasaran, Donney and Cannon (1997:36) mendefinisikan "Trust as perceived credibility and benevolence of a target of trust." Dari definisi ini trust dapat dilihat dari dua dimensi. Dimensi pertama adalah : "credibility of an exchange partner, and expectancy that the partner word or writter statement can be relied on. Dimensi kedua benevolence is the extent to wish one partner is genuinely interested in the other partner's welfare and motivated to seek joint again". 
Morgan dan Hunt (1994:50) mendefinisikan kepercayaan sebagai keyakinan seseorang terhadap reliabilitas dan integritas pihak lain. Sependapat hal tersebut Callaghan, (1995:12) mendefinisikan bahwa kepercayaan sebagai dimensi hubungan bisnis yang menentukan tingkat sehingga orang merasa dapat bergantung pada integritas janji yang ditawarkan oleh orang lain. Hal ini secara mendasar merupakan keyakinan bahwa seseorang akan memberikan apa yang dijanjikan.

Dalam proses terbentuknya kepercayaan (trust), Donney and Comion (1997:3) menjelaskan secara rinci faktorfaktor yang mempengaruhinya seperti, reputasi perusahaan, besar/kecilnya perusahaan, saling menyenangkan, baik antara pelanggan dengan perusahaan maupun antara pelanggan dengan pegawai perusahaan. Kepercayaan konsumen diyakini berperan dalam pembentukan persepsi pelanggan dalam hubungan mereka dengan perusahaan jasa (Taylor, 2001:32). Kepercayaan (trust) adalah satu penentu utama dalam relationship commitment (Morgan dan Hunt, 1994:24), sedangkan Bloemer et.al (1998:69) menyatakan kepercayaan (trust) merupakan mediator antara kepuasan dan loyalitas. Garbarino dan Johnson (1999:71) juga lebih menekankan pada individual trust dengan mengacu kepada keyakinan konsumen atas kualitas dan keterandalan jasa yang diberikan.

Berdasarkan hal tersebut kepercayaan harus menjadi komponen fundamental dalam strategi pemasaran yang ditujukan untuk mengarah pada penciptaan customer relationship yang baik. Untuk dapat menciptakan loyalitas perusahaan harus dapat membuat pelanggan mengandalkan perusahaan dalam memenuhi kebutuhan akan jasa dan produk. Namun membangun kepercayaan bukan merupakan hal mudah bagi perusahaan, membutuhkan waktu yang lama dan hanya tercipta setelah pelanggan mengalami atau mengkonsumsi produk atau jasa perusahaan. Membangun hubungan yang dapat dipercaya akan lebih mungkin terjadi dalam sektor industri tertentu, terutama yang melibatkan pengambilan risiko oleh pelanggan dalam jangka pendek atau jangka panjang (Barnes, 2003:149).

Kepercayaan (trust,) adalah keyakinan pada pihak yang mempunyai integritas tinggi, yang disertai dengan kualitas tertentu yang konsisten, kompeten, jujur, adil, bertanggung jawab, membantu dan baik (Morgan dan Hunt, 1994:23). Trust timbul dari suatu proses yang lama sampai këdua belah pihak saling mempercayai. Apabila trust sudah terjalin di antara pelanggan dan perusahaan, maka usaha untuk membinanya tidaklah terlalu sulit. Sehubungan dengan kenyataan bahwa sifat jasa yang tidak bisa dilihat (Intangible), maka karyawan maupun rekan bisnis menjadi faktor yang memudahkan terciptanya hubungan yang berdasarkan kepercayaan. Perusahaan yang sudah dipercaya akan berkurang ketidakpastiannya (uncertainty) maupun kerapuhannya (vulnerability), karena memiliki rasa percaya diri yang sangat baik, yang membuat perusahaan mampu mengatasi banyak masalah.

Studi tentang keyakinan pelanggan adalah merupakan bagian dari relationship pelanggan/ pemasaran, hal ini dikemukakan oleh Solomon (1996) bahwa pandangan strategi yang menekankan jangka panjang dan merupakan interaksi dari sisi kemanusiaan pembeli dan penjual. Ini memfokuskan pentingnya hubungan relasional dengan membangun komitmen dan keyakinan dengan pelanggan.

Beberapa situasi dan indikator dari trust dikatakan oleh Mitchell dalam Egan (2001), sebagai berikut : Probity (fokus kepada kepercayaan dan integritas dan reputasi); Equity (berkaitan dengan fairmindedness, benevolence); Reliability (berkaitan dengan keandalan dan ketepatan serta konsistensi dari produk atau servis yang diharapkan dalam beberapa hal berkaitan dengan garansi yang dikeluarkan oleh perusahaan). Jika perusahaan dapat menunjukkan trustworthy kepada pelanggan maka pelanggan akan percaya kepada 
perusahaan dan pola hubungannya (Storbacka, 2001).

Griffin (2002) mengatakan bahwa yang ada dipikiran pelanggan pada saat dia ingin mengadakan hubungan adalah apakah perusahaan dapat dipercaya, artinya kepercayaan pelanggan pada perusahaan yang bergerak dalam bidang jasa merupakan suatu aset bagi perusahaan, sehingga menjaga kepercayaan pelanggan menjadi suatu hal yang perlu diprioritaskan oleh perusahaan untuk menjaga loyalitas pelanggannya. Demikian juga Fournier, Susan; Susan Dobscha and David Glen Mick (1998) menjelaskan bahwa untuk memperoleh kepercayaan pelanggan perusahaan harus berbuat sedemikian rupa yang menunjukkan pada pelanggan bahwa perusahaan mempunyai nilai jika dijadikan partner. Kita harus membuktikan dengan aksi bahwa hubungan dengan pelanggan harus mempunyai arti dan dibuat sebaik-baiknya.

Dalam penelitian ini menguraikan masalah kepercayaan pasien rawat inap pada RSUD di Kepulauan Riau yang dibahas dari sisi: Probity (fokus kepada kepercayaan dan integritas dan reputasi); Equity (berkaitan dengan fair-mindedness, benevolence); Reliability (berkaitan dengan keandalan dan ketepatan serta konsistensi dari produk atau servis yang diharapkan dalam beberapa hal berkaitan dengan garansi yang dikeluarkan oleh perusahaan). Jika perusahaan dapat menunjukkan trustworthy kepada pelanggan maka pelanggan akan percaya kepada perusahaan dan pola hubungannya yang menggunakan pendapat Storbacka (2001).

\section{METODE}

Penelitian ini menggunakan metode kualitatif, melalui wawancara kepada pasien dan pihak RSUD Kepualauan Riau berkaitan dengan masalah kepercayaan pasien terhadap rumah sakit khusus pada pasien rawat inap. Analisis data menggunakan analisis deskriptif.

\section{HASIL}

Kepercayaan sebagai dimensi hubungan bisnis yang menentukan tingkat di mana orang merasa dapat bergantung pada integritas janji yang ditawarkan oleh orang lain. Hal ini secara mendasar merupakan keyakinan bahwa seseorang akan memberikan apa yang dijanjikan. Morgan dan Hunt, (1994) Barnes (2003),

1. Kemampuan (Ability)

Kemampuan (Ability), meliputi beberapa hal antara lain kemampuan dokter dalam mendianosa penyakit pasien; kemudian kemampuan dokter menetapkan riwayat penyakit pasien; kemampuan dokter menetapkan resep obat; kemampuan dokter memeriksa sesuai historis sesuai penyakit; kemamuan seorang dokter melaksanakan sesuai standard kompetensi; kemampuan doker dalam memanfaatkan alat-alat kedokteran; jaminan keamanan dalam proses pengobatan; daya tanggap dokter kepada pasien; keramahan Dokter ketika menangani pasien; kepedulian Dokter terhadap keberadaan pasien dan empati Dokter kepada pasien.

Berdasarkan hasil wawancara di lapangan dengan pasien di RSUD Kepulauan Riau khususnya pasien rawat inap, dapat diketahui beberapa jawaban informan yang mengarah kepada masih belum optimalnya kemampuan dokter dalam menyembuhkan penyakit pasien yang ada. Hal ini menyebabkan pasien yang memiliki kemampuan lebih besar dibandingkan pasien masyarakat kebanyakan mereka memilih rumah sakit yang lebih baik dalam hal kemampuan. Selain itu juga masalah kemampuan ini juga menjadi kendala bagi masyarakat karena keterbatasan jumlah dokter yang mampu melayani masyarakat menyebabkan pada dokter yang memiliki kemampuan lebih atau dikatakan dokter yang "hebat" akan mendapatkan banyak pasien dibandingkan dokter yang biasa saja.

Kebanyakan dokter yang ada masih muda dan baru dan dianggap masyarakat belum memiliki pengalaman yang baik dalam menangani pasien. Hal ini menyebabkan 
kepercayaan pasien terhadap dokter yang cenderung lebih rendah. Penyebab hal ini lebih mengarah kepada masalah keinginan atau motivasi dokter, karena dapat dilihat dari tanggapan informan dijelaskan bahwa dokter yang memiliki kemampuan akan membuka praktek sendiri dan bahkan mencari tempat yang lebih ramai lagi, sedangkan untuk mengabdi di masyarakat menjadi suatu hal yang kurang diperhitungkan.

\section{Integritas (Integrity)}

Integritas (Integrity), meliputi kewajaran biaya dengan kualitas layanan yang diberikan; pemenuhan harapan pasien; kesetiaan pasien terhadap institusi rumah sakit; kejujuran dokter dalam menyampaikan informasi ke pasien; dan jaminan kualitas kesehatan yang disampaikan kepada pasien.

Dari jawaban informan mengenai masalah integritas ini mengarah kepada keinginan pasien untuk pindah ke rumah sakit lain, memang dirasakan masih kurang. Hal ini karena keterbatasan biaya yang dimiliki pasien karena dalam RSUD tersebut, pembiayaan lebih murah dan bahkan ada yang gratis. Walaupun bagaimana bentuk pelayanan yang diberikan tidak akan memberikan pengaruh kepada pasien untuk pindah ke tempat lain yang memakan biaya lebih mahal.

Kondisi pembiayaan di RSUD Kepulauan Riau ditanggung pemerintah, anggaran rumah sakit masih dalam APBD dan ini menjadi peluang tersendiri bagi rumah sakit dalam meningkatkan pelayanan jasanya. Namun kondisi lainnya mengarah kepada Karena terlalu ramainya dan keterbatasan jumlah kemampuan rumah sakit sehingga pasien kurang mendapatkan perawatan yang lebih baik seperti yang diharapkan.

\section{Kebijakan (Benevolence)}

Kebijakan (Benevolence), meliputi perhatian dokter terhadap harapan paien; perhatian perawat terhadap harapn pasien; kepedulian dokter terhadap pasien yang mengalami kesulitan pada saat pengobatan/pemerik-saan dan perawatan; keyakinan pasien terhadap kualitas pengobatan yang diterima; kesediaan dokter meluangkan waktu untuk pasien berkonsultasi; penerimaan pasien atas jasa kesehatan yang diterimanya.

Saat ini dari hasil wawancara yang dilakukan pemerintah dalam hal ini melalui direktur RSUD membuat kebijakan yang mengarah service excellence, hal ini dilakukan dan dalam penerapannya memang masih belum optimal. Secara formal sudah dapat dilihat dari motto rmah sakit dalam melayani pasien. Namun pasien masih belum mendapatkan pelayanan secara iklas dari petugas rumah sakit itu sendiri. Kondisi ini memang dinilai dari pimpinan rumah sakit sebagai bentuk pelayanan yang subjektif dari masyarakat penerima pelayanan. Walaupun dari pihak rumah sakit sudah memberikan pelayanan lebih baik, namun hal yang wajar jika penilaiannya dari masyarakat masih apa adanya.

\section{PEMBAHASAN}

Berdasarkan hasil penelitian di atas, maka jelas bahwa kepercayaan pasien rawat inap terhadap RSUD Kepulauan Riau sudah cukup baik, hal ini dilihat dari integritas dan kebijakan rumah sakit yang pro masyarakat. Walaupun belum ditopang oleh tenaga dokter yang memadai. Sehingga walaupun kondisinya kurang sesuai dengan yang diharapkan pasien, namun pasien tetap saja mau berobat ke RSUD Kepulauan Riau. Hal ini disebabkan oleh berbagai faktor yang membuatkan kondisinya demikian.

Hasil penelitian ini memberikan gambaran bahwa dalam mengukur kepercayaan menggunakan beberapa indikator seperti indikator kemampuan, integritas dan juga kebijakan. Namun dalam penelitian ini menambah indikator lainnya yakni kearifan lokal, dimana dalam memberikan pelayanan kepada pasien, diharapkan lebih meningkatkan tata krama atau tutur kata yang lebih baik dan bersikap apa adanya sehingga pasien lebih gambling dalam menerima berbagai kondisi yang dirasakannya. Penelitian ini mendukung 
penelitian sebelumnya yakni pendapat Storbacka (2001).

\section{SIMPULAN}

Kepercayaan merupakan perilaku yang di dalamnya mengarahkan kepada penilaian terhadap sebuah tindakan atau sikap yang diberikan. Kepercayaan ini berdampak terhadap keberlanjutan sebuah pelayanan itu sediri. Dalam hal pelayanan jasa rumah sakit, pelayanan menjadi hal penting dalam membuat pasien mau dan terus menggunakan jasa rumah sakit. Banyak keluhan dan membuktikan bahwa pada RSUD Kepulauan Riau, masalah yang paling mendasar yang perlu dibangun adalah masalah kemampuan dokter daam menyembuhkan penyakit pasien.

\section{DAFTAR RUJUKAN}

Barnes, 2003, Secrets Of Customer Relationship Management, ANDI,. Yogyakarta.

Bloemer et.al, 1998, Customer Loyalty in a Service

Callaghan dan Shaw, 1995, Social Capital: A Missing Link to Disaster Recovery.

Donney and Cannon, 1997, An Examination of the Nature of Trust in. BuyerSeller Relationship, Journal of Marketing,

Garbarino dan Johnson, 1999, The Different Roles of satisfaction. Journal of. Marketing, Customer Trust, Value, and. Loyalty

Griffin, 2002, Customer Loyalty How to Earn It, How to Keep It

Gurviez and Korchia, 2003, Development and Validation of A Brand Trust Scale

Hardiman, 2003, Rumah Sakit Indonesia Belum Siap Bersaing

Keputusan Menteri Kesehatan RI No. 983 Tahun 1992, tugas pokok rumah sakit

Kreitner dan Kinicki, 2001, The Strange Case of The Transfer of Training estimate.
Mitchell dalam Egan, 2001, People in Organization Understanding Their

Morgan dan Hunt, 1994, Determinants of Longterm Orientation in BuyerSeller.

Peraturan Menteri Kesehatan Republik Indonesia NOMOR 340/MENKES/PER/III/2010 tentang klasifikasi rumah sakit

Robbin, 2003, Prinsip-prinsip Perilaku Organisasi, PT. Erlangga

Rotters, 1997, Genaralized Expectancies for Internal Versus External control.

Solomon, 1996, Organic Chemistry", 5th ed, John Wiley \& Sons, New York

Storbacka, 2001, Customer Relationship Management: Creating Competitve Advantage thourgh Win-win

Susan Dobscha and David Glen Mick, 1998, Preventing the Premature Death of Relationship Marketing. Susan Fournier

Taylor, 2001, Riset Pemasaran

Undang-Undang Republik Indonesia Nomor 23 Tahun 1992 tentang PokokPokok Kesehatan disebutkan

Undang-Undang Republik Indonesia Nomor 44 Tahun 2009 Tentang Rumah Sakit

Wells dan Prensky, 1996, Consumer Behavior, New York: John 